\title{
TOWARDS A HYBRID UNIVERSITY EDUCATION, INTEGRATION OF MOOCS IN INITIAL TRAINING PROGRAMS: A CASE OF A BIG PRIVATE EDUCATION STRUCTURE IN MOROCCO
}

\author{
Bouchaîb Riyami ${ }^{1,2}$, Khalifa Mansouri ${ }^{2}$, Franck Poirier ${ }^{1}$ \\ ${ }^{1}$ Lab-STICC Sciences et Techniques de l'information, de la Communication et de la \\ Connaissance, UBS University, Vannes (FRANCE) \\ ${ }^{2}$ Signals, Distributed Systems and Artificial Intelligence (SSDIA), Hassan II University, \\ Casablanca (MOROCCO)
}

\begin{abstract}
For several decades, the main elements of the educational triangle of higher education in Morocco: the teacher, the learner and the knowledge very marginally profited from information and communication technologies (ICT). But with the explosion of the learning management systems as Moodle, platforms of electronic learning such as MOOC (Massive Open Online Courses) and the appearance of the new mobile devices as smartphones and tablets, the process of initial training in the Moroccan universities changed a lot and in-depth.

This article presents the experience of implementation of an integration process of distance learning platforms such as MOOCs in programs of initial trainings of a big private structure of higher education in Morocco for the benefit of 2000 students, distributed on eight training centers and supervised by approximately 250 teachers.

The paper will handle the general concept of the issue problem, the modelling and the implementation of the process of integration, the motivation mechanisms of the teachers and the learners to pursue them during the phase of the change, the control system and the follow-up of the feasibility by the P3M (Principal Permanent Professor MOOC), conditions of use (isolated or collaborative), as well as the proposal of a hybrid evaluation system.

The paper presents the advantages, interests and saving (time and costs) generated from this experience, as well as the moral and material values created through the integration of this process in trainings within the university group under question and in particular the increase of the success rate of the students.
\end{abstract}

Keywords: ICT, MOOC, Moodle, face-to-face training, distance training, educational system, evaluation system, hybrid evaluation.

\section{INTRODUCTION}

Today, the success of MOOCs (Massive Open Online Courses) is not limited only to their openness to all heterogeneous learners, but also in their integration into the curricula of initial training in higher educational institutions. In the latter case, it is a very different situation of the opening to the public because it is no more about free learners (often industrial professionals), but it is rather students groups following their mandatory courses as part of their initial degree training curriculum. In case of requirement of these parallel training as part of initial training, we will analyze the situation in a double: the rate of satisfaction of learners and teachers in the use of MOOCs and success rate in the achievement of the aimed objectives.

In this article, we present the experience of implementing an integration process of distance learning platforms MOOCs into the curricula of initial training of a large private higher education structure for the benefit of 2000 students spread over eight training centers and supervised by about 250 teachers.

In the first part, we recall the general context of the research, and then we describe the process of integrating MOOC in initial training courses in the higher education group. We then present the motivation mechanisms for learners and teachers, and try to introduce a System of assessment and traceability of learners in MOOC as well as a dual assessment system. Finally, we present the benefits, interest and savings derived through the use of this educational approach. 


\section{GENERAL RESEARCH CONTEXT}

The general context of our research is about the experience of implementing a process of integration of distance learning platforms in initial training curriculum of a private higher education group in Morocco. Since its creation in 1981, the group uses a policy of excellence enabling it to rise to the top ranks of private higher Moroccan engineering and management schools distinguishing itself by the quality of the training of its graduates, its close ties with business partners, its dense network of former graduates and its influence both nationally and internationally.

Today in figures, the group consists of:

- Eight training centers nationwide, three centers in Casablanca, one in Rabat, one in Marrakech, a one in Fez, a one in Eljadida and one in Settat.

- Thirty-five years of experience in the field of Moroccan private higher education.

- Over 250 permanent teachers and individual contractors.

- More than twenty outsourced training in alternation with French partner universities (UBS southern Brittany, Lorraine, Rennes, Perpignan, Tours, Lyon 1, Upper Alsace, INSA Lyon).

- Over ten thousand winners in the job market.

- More than students from more than 20 countries.

- More than ten higher education courses accredited by the state.

- Several certificates prepared by the students of the group, such as $\mathrm{CISCO}^{1}$ Certified IT PEARSON VUE ${ }^{2}$.

Since the creation of the group and along several years, all initial, continuous and outsourced foreign universities are held-face-to-face. But today it has chosen to follow the following trends:

- Integration of distance learning platforms open to all the public as MOOCs.

- Use of digital content management e-learning platforms as Moodle

- Application of the set of the Higher Education Ministry which states, for new processes of accreditation, integration, in all courses, of distance learning via a MOOCs or LMS (Learning Management Systems) to diversify the style of training.

- Monitoring the experience of launching the first MOOC platform by the University Hassan II in Casablanca in January 2015 [5].

According to the above trends, our group is obliged to integrate MOOCs in the initial training course as an experience based on a precise specification to enhance its classical traditional face-to-face system and achieve other specific objectives related to the quality of training, such as:

- Heavy use of information and communication technologies in the field of education (ICTE).

- Alignment of group trends and innovation of information and communication technologies ICT in education systems.

- Opening internationally to improve its levels of learners.

- Interaction of the group's students with students from around the world via discussion forums of MOOC.

- Interaction of the group's teachers with their students and with teachers and learners around the world to enrich their experiences in teaching.

- Learners build their knowledge by themselves without the presence of his teacher.

\footnotetext{
${ }^{1}$ https://www.netacad.com

${ }^{2}$ http://home.pearsonvue.com
} 
But beyond this observation, we set the following methodological issues:

- How to motivate students to use MOOC in their learning?

- How to motivate teachers to use MOOCs to complement their teaching materials?

- What MOOC to be used for a given level in the course of initial training? And why?

- How do teachers assess learners during using MOOC?

\section{MODELING AND IMPLEMENTATION OF THE INTEGRATION MOOC PROCESS}

\subsection{Presentation of the traditional curriculum of initial training of the group}

The initial training curriculum of the group are conducted in face-to-face and for five years of study, both for engineering (Figure 1) and for management (Figure 2).

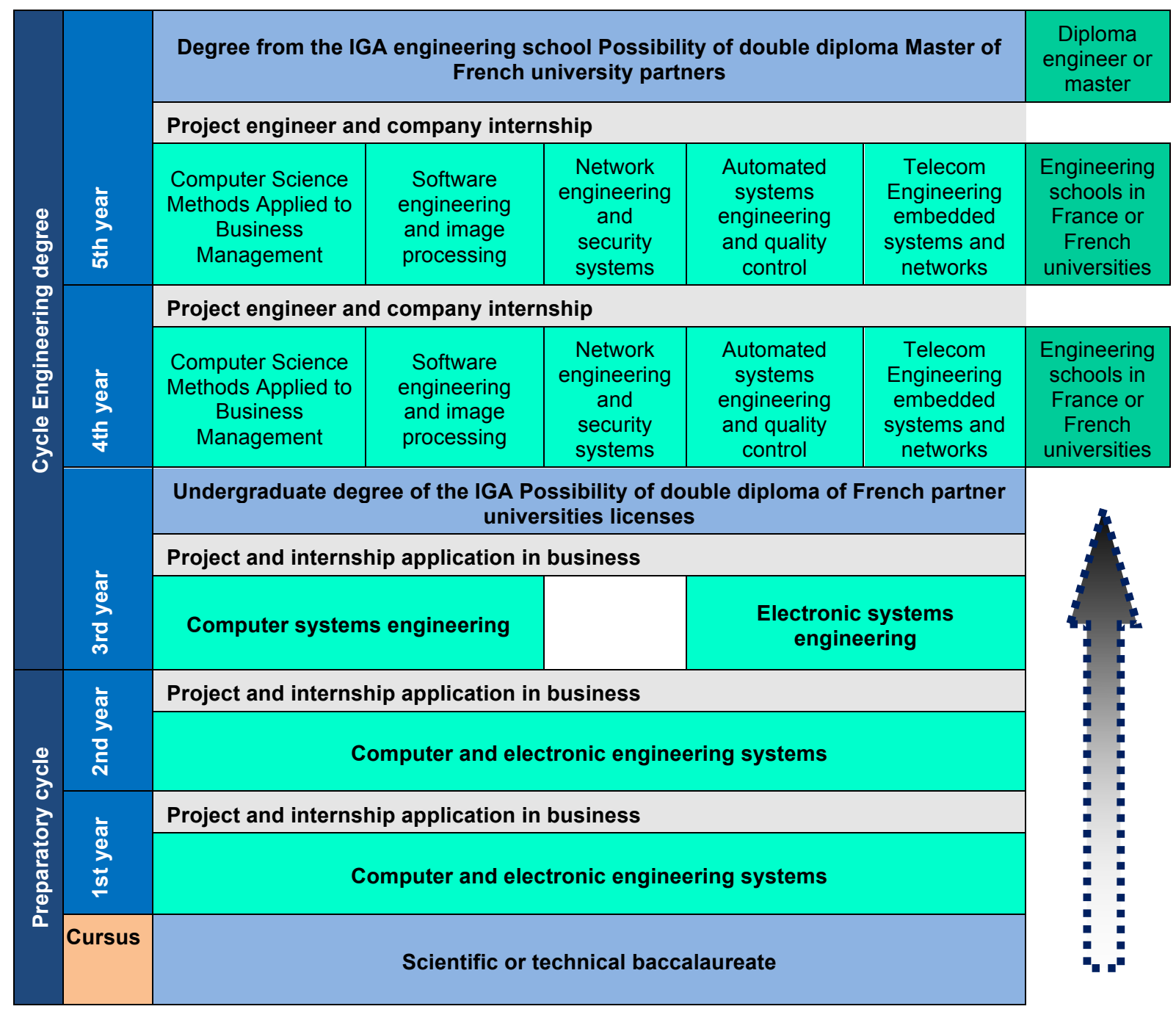

Figure 1: Traditional initial training Curriculum: Engineering 


\begin{tabular}{|c|c|c|c|c|c|}
\hline \multirow{2}{*}{ 㫕 } & \multirow{2}{*}{ ㄷㅀㅎ } & \multicolumn{3}{|l|}{ DEC - Accounting degree } & \\
\hline & & \multicolumn{3}{|c|}{ DSCG - Higher Diploma in Accounting and Management } & \\
\hline \multirow{8}{*}{ 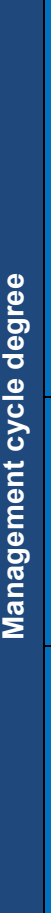 } & \multirow[b]{3}{*}{ 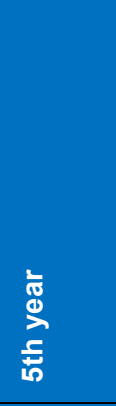 } & \multicolumn{3}{|c|}{$\begin{array}{l}\text { Degree from the IGA engineering school Possibility of double diploma Master of } \\
\text { French university partners }\end{array}$} & $\begin{array}{l}\text { Manageme } \\
\text { nt school } \\
\text { diploma or } \\
\text { master }\end{array}$ \\
\hline & & \multicolumn{3}{|c|}{ Project and business manager internship } & \\
\hline & & $\begin{array}{l}\text { Information System Audit } \\
\text { and Management Control }\end{array}$ & $\begin{array}{l}\text { Information and Financial } \\
\text { Engineering System }\end{array}$ & $\begin{array}{l}\text { Information System } \\
\text { Marketing and Trade }\end{array}$ & $\begin{array}{l}\text { Business } \\
\text { schools in } \\
\text { France or } \\
\text { French } \\
\text { universities }\end{array}$ \\
\hline & \multirow[b]{2}{*}{ 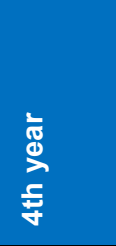 } & \multicolumn{3}{|c|}{ Project and business manager internship } & \\
\hline & & $\begin{array}{l}\text { Information System Audit } \\
\text { and Management Control }\end{array}$ & $\begin{array}{l}\text { Information and Financial } \\
\text { Engineering System }\end{array}$ & $\begin{array}{l}\text { Information System } \\
\text { Marketing and Trade }\end{array}$ & $\begin{array}{l}\text { Business } \\
\text { schools in } \\
\text { France or } \\
\text { French } \\
\text { universities }\end{array}$ \\
\hline & \multirow{3}{*}{ 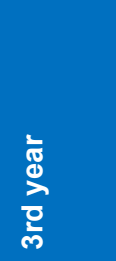 } & \multicolumn{3}{|c|}{$\begin{array}{l}\text { Undergraduate degree of the IGA Possibility of double diploma of French } \\
\text { partner universities licenses }\end{array}$} & \\
\hline & & \multicolumn{3}{|c|}{ Project and internship application in business } & \\
\hline & & $\begin{array}{l}\text { Information System } \\
\text { Finance and Control }\end{array}$ & & $\begin{array}{l}\text { Information System } \\
\text { Marketing and Trade }\end{array}$ & \\
\hline \multirow{5}{*}{ 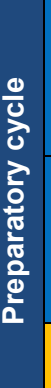 } & 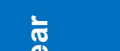 & \multicolumn{3}{|c|}{ Project and internship application in business } & \\
\hline & ㅎำ & \multicolumn{3}{|c|}{ Information systems and business management } & 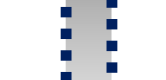 \\
\hline & \multirow{2}{*}{$\begin{array}{l}\frac{5}{\$} \\
\stackrel{\$}{2} \\
\stackrel{0}{\sigma}\end{array}$} & \multicolumn{3}{|c|}{ Project and internship application in business } & \\
\hline & & \multicolumn{3}{|c|}{ Information systems and business management } & $:$ \\
\hline & Cursus & \multicolumn{3}{|c|}{ Bachelor all options } & \\
\hline
\end{tabular}

Figure 2: Traditional initial training Curriculum: Business Management

In general, and in both cases, the initial training courses in engineering courses and those of business management, the first two years are considered preparatory years in which, students follow a general and versatile training. From the third year, students choose a specialization, fourth, and fifth year, they choose again a second greater specialization.

\subsection{Modeling and implementation of the integration MOOC process}

To improve the initial training curriculum in our group and align its educational system to current trends in international educational systems as in the case of micro master, experience launched by the USA [2][10]. Integrating of information and communication technologies (ICT) in its education system, we propose a hybrid teaching process [9], a part of it consists of face-to-face training and another part of it is distance learning through the world-famous e-learning platforms such as ABC MOOC Project Management [22], Coursera, EdX, FUN, Udacity, khan academy and OpenClassroom.

According to the programs of initial training courses, the blended learning process (set of hybrid training) must be adapted to different levels of options and pathways, and must meet specific requirements in education for the group. For this reason, we have applied the hybrid teaching process at each level of initial training for each sector after discussions with the group managers, and from our experience as trainers of ICT for more than fifteen years. 
Table 1: The integration process of MOOC for each level of initial training of the two streams of group in question.

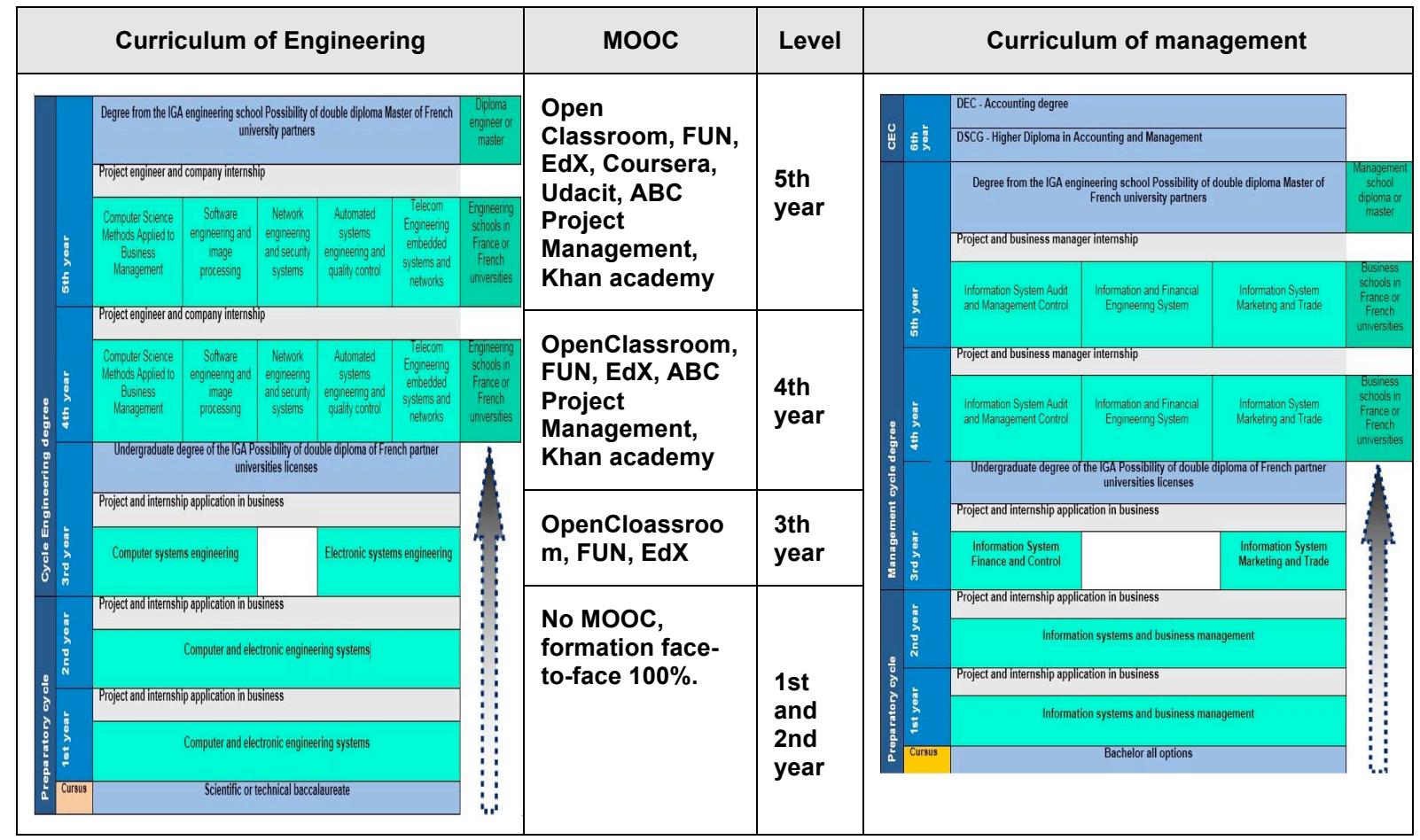

Table 1 presents our proposed process for integrating $\mathrm{MOOC}$ at each level of initial training curricula of both engineering and management. And for each level, we have proposed MOOC according to their degrees of difficulties and their educational content.

\subsection{Justification}

From Table 1, the first two years of initial training courses are face-to-face about $100 \%$, as learners, arrive very young, without experience and without autonomy, just after obtaining their bachelor's degrees to integrate higher studies. They have many gaps as for the use of Information and Communication Technologies (ICT). These two years are considered preparatory base years in which they need are $100 \%$ face-to-face supervising. So we will not integrate MOOC along the first year of training.

From the third year, we have proposed the integration of MOOC as Open classroom, FUN and EdX with a rate of about $25 \%$, and the rest of the training is face-to-face. The MOOCs proposed at this intermediate level offer courses to the public of all levels beginner, intermediate and advanced. The MOOCs are XMOOC (MOOC transmissive) [12], that is to say, they have the same educational approaches that the traditional face-to-face system has and their educational content are composed of videos, documents, work directed to quiz and practical workshops.

OpenClassroom is a distance-learning platform, which offers courses to students in the form of stepby-step tutorials, web oriented, general computer and business management modules. It is the European leader in the MOOC sector.

EdX: MOOC is an open source, which provides learners with training modules for beginners, intermediate and advanced, and most of the courses are in English. The course modules are in the form of videos, Word documents, PDF and PowerPoint. It is a US platform and its partners are the most prestigious universities in the world such as MIT (Massachusetts Institute of Technology), Harvard University and University of California Berkeley [11].

FUN: is a French MOOC platform, which offers courses with the same principle as EdX, It is technically supported by the open source, open EdX platform and supported by Google since September 2013 [6].

For the fourth year levels of training courses within our group, we have proposed the same MOOC platforms used in the third year, plus two other platforms $A B C$ Project Management and Khan 
Academy with a rate of about $50 \%$. This choice is motivated by the fact that at the fourth year, all options and fields of study have a first training module about project management. We think that the best MOOC platform suitable for this module is the MOOC ABC project management, which is animated by the best teachers of the school and the center of Lille supervised by Professor Rémi Bachelet [20]. The second introduced module, concerning mathematics, statistics, and operations research and optimization techniques. We found that the MOOC Khan Academy specializes in preparing learners for mathematics exams, is the most suitable for this training module.

For the fifth year level of all fields of study and options, we have increasingly proposed, Coursera and Udacity MOOC, increasing the utilization rate to about $75 \%$. As students have achieved a high level of maturity in distance learning. In addition, our group offers to its students to follow the initial training courses during the day or evening. Learners at this level don't need a direct supervision by teachers except by a rate of $25 \%$ in training. Among the benefits that one can also cite the MOOC digital content that is richer and includes advanced modules and adapted at this level such as: business intelligence, business games, advanced databases, pricing policy, product politics, CRM, etc. [7].

\section{LEARNERS AND TEACHERS MOTIVATION MECHANISMS}

In our approach, we invite teachers to attend periodic and ongoing training organized by our group on MOOCs platforms [1]. And through these continuous training, teachers will have the opportunity to interact with teachers from around the world to [14], share their experiences with other teachers, enrich their educational content for digital content shared with teachers of the best schools and university in the world such as MIT, Harvard University, Stanford. And to use the digital content made available by MOOCs as MOOC ABC Project Management works of to hand in Rémi Bachelet [19] providing content as a PDF, doc, video, quizzes, and work to make.

As for teachers of our group who are aligned to this new approach to teaching, they have to respect the clauses of periodic continuous training offered by the group on the one hand. Also to explain and share the great benefits of MOOCs platforms of profiles' learners, and accompany learners throughout the period of a programmed module on the MOOC.

Note also that there are other motivational projects for teachers on information and communications technologies (ICT) for education, set up by government departments as INJAZ [3] LAWHATI [4], mainstreaming of ICT [13] and MARWAN [16].

The MOOCs platforms provide learners with supporting documents at the end of the online training. These documents are certificates, certificates of participation or badges, which motivate learners to take courses on MOOCs hoping to also, improve the quality and content of their CVs [21].

We have also proposed to our group, in the motivational part of learners on the use of MOOCs, and as part of quality control, communication and marketing to distribute to learners tablets or mini netbooks with a broadband connection. With this motivation, the group will have more students in the coming years and may include costs incurred in the purchase of such equipment and included in student registration fees [17].

\section{TRACKING CONTROL SYSTEM OF LEARNER TRAINING.}

Our group has established a teacher-based P3M (Principal Permanent Professor MOOC) having as a role to control MOOCs responsible teacher of each level of the curriculum. That are the items checked are: the interactions between learner-learner, learner-teacher and teacher-teacher, the online courses continuity monitoring and management of locks and problems of MOOCs.

In our educational approach and in this control and traceability system for teachers and learners, we offer the mapping presented in Figure 3. 


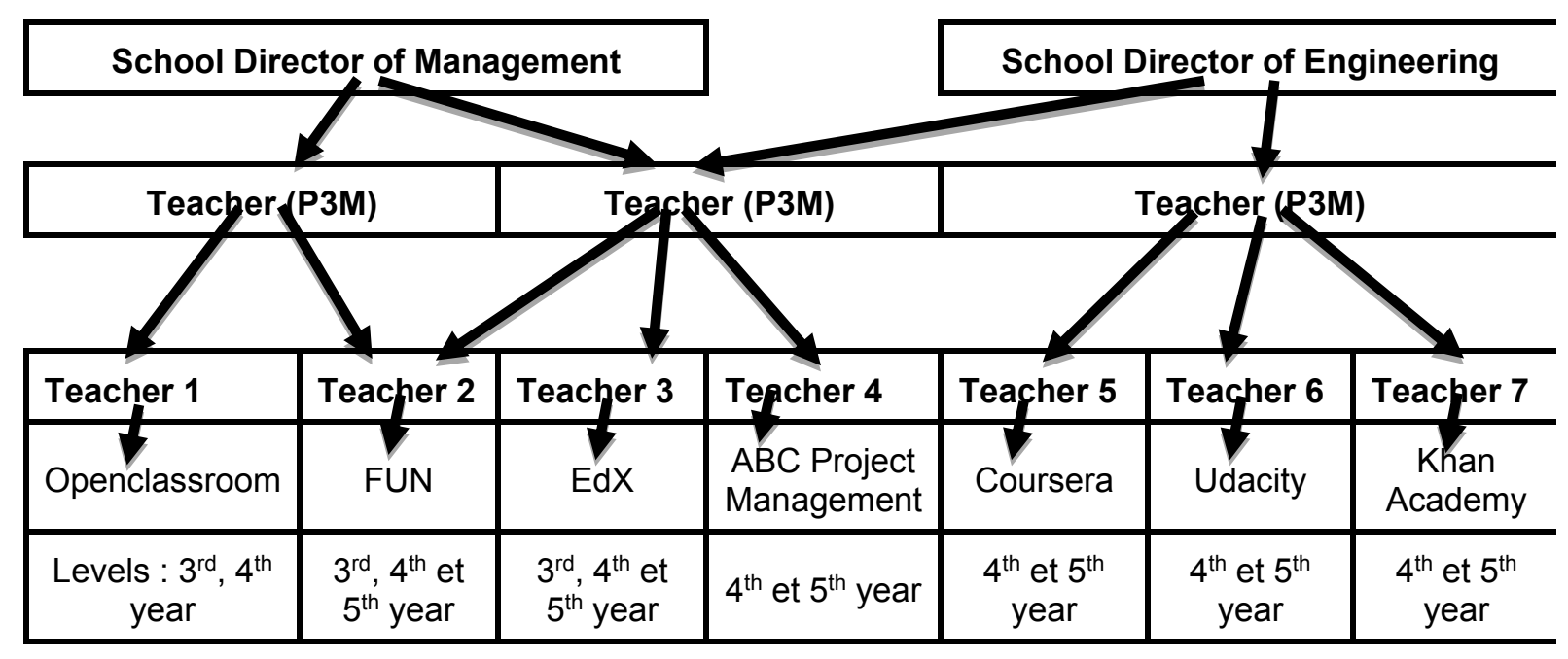

Figure 3: Mapping of control and traceability system for teachers and learners by P3M

In this control approach, we propose the following approach as motivation for the successful integration of MOOCs in initial training curriculum of our group.

- Each P3M teacher is responsible for monitoring the works of supervising of one or more teachers per MOOC platform and level.

- Each teacher is assigned to a MOOC platform, according to his/her specialty and population (same level of several centers), and responsible for overseeing the public and is supervised by a P3M.

- Each teacher is responsible for controlling all interactions learners together, and the interactions of learners in quizzes, multiple choice and work to hand in.

- End of the semester, teachers are to prepare a report to be given to P3M to assess learners according traceability interactions carried out and according to a dual assessment system we are proposing in the next paragraph.

\section{HYBRID EVALUATION SYSTEM}

The current MOOC platforms tend to integrate online assessment activity of a large number of learners at the same time. The question that is always asked is, whether or not a learner should be assessed after training made on a MOOC. And if so, why should he/she be assessed? And what is the right way to get a better assessment and verify the validity of this distance assessment?

We should evaluate to educate learners about the importance of the use of MOOC, and to help them validate their achievements and therefore advance in their training. But the big problem is that we are in a logic of self-study and individual work which could lead to cheating or plagiarism which may distort the expected assessment.

There are several ways to assess learners online like automatic assessment, peer assessment and self-assessment [15].

We can note several ongoing research on the integration of online learner's evaluation activities, such as the work launched by the designers of the EDX MOOC platform hosted by MIT and Harvard University, and fifteen other world universities. These designers have announced the creation of an automatic correction software short answer to questionnaires, tests, homework, essays and critical analyzes [8].

In our approach, we consider that the online assessment is not sufficient, that is why we offer a hybrid evaluation system hoping for the success of the experience of in integrating MOOCs in initial training courses of our group. This can be described as follows:

- Following courses on the MOOC platforms'.

- Tracking and tracing the interactions and works of learners by their teachers on MOOCs. 
- Quizzes, multiple choice answers (MCA) and works to hand in by learners via automatic evaluation platform MOOC.

- Reception for validation of MOOC supporting documents such as certificates, badges or certificates of participation in the chapters of the course.

- Back in class to take face-to-face exams, monitored by a conventional evaluation by the teacher or the teaching team.

These points lead us to propose a final assessment on the following criteria:

Final mark = Average (face-to-face exam + learners traceability + supporting documents).

Learners traceability = Average (Quiz mark + MCA mark + peers mark)

Peers mark = an evaluation mark given by learners to each other [15].

Supporting documents $=\mathrm{MOOC}$ certificate or badge or certificate of participation

\section{EARNINGS, BENEFITS AND SAVINGS DERIVED BY THE GROUP USING THIS APPROACH}

The teaching model and the hybrid evaluation process of learners that we have proposed had many benefits, interest and produced a lot of savings for our group, and had a big positive impact on all learners, teachers and the teaching staff (see table 2).

Table 2: Advantages, interest and savings from using the new hybrid-teaching model.

\begin{tabular}{|c|c|c|}
\hline Advantages & Interests & Savings \\
\hline $\begin{array}{l}\text { - Openness of learners and } \\
\text { diversification of information } \\
\text { resources. } \\
\text { - Learners can benefit from the } \\
\text { experiences of other learners } \\
\text { in the world. } \\
\text { - Teachers can improve their } \\
\text { teaching methods, their } \\
\text { educational content and } \\
\text { experiences. } \\
\text { - Relieve the teaching team } \\
\text { through the automatic } \\
\text { feedback, through self- } \\
\text { assessment and peer review. }\end{array}$ & $\begin{array}{l}\text { - Learners enjoy the best } \\
\text { digital educational content. } \\
\text { - Learners work in groups and } \\
\text { in better conditions according } \\
\text { to programmed time slots on } \\
\text { MOOCs. } \\
\text { - Learners construct their } \\
\text { knowledge themselves. } \\
\text { - Teachers take advantage of } \\
\text { periodic and ongoing training } \\
\text { on MOOC organized by our } \\
\text { group. }\end{array}$ & $\begin{array}{l}\text { - More free space in the } \\
\text { premises of the group, the } \\
\text { fact that students learn } \\
\text { online, at home or in groups } \\
\text { in public spaces. } \\
\text { - Teaching teams relieved and } \\
\text { simply guide learners at } \\
\text { weekly meetings to meet } \\
\text { specific needs of learners. } \\
\text { - The foreign teachers should } \\
\text { travel less which would. }\end{array}$ \\
\hline
\end{tabular}

\section{CONCLUSION AND PERSPECTIVES}

Through this contribution, we were able to show the experience of a private university group in Morocco in the establishment of a new hybrid learning process that responded to very specific needs.

The integration of the approaches we have proposed in this article and which is primarily based on hybrid teaching process, the hybrid evaluation system [23], the motivation of learners and teachers had much impact on this group and generate many benefits, interests and tangible and intangible savings. However, this approach is limited to local initial training curriculum of the group without having the opportunity to expand it to other continuing education ${ }^{3}$, and outsourced training in collaboration with French universities.

In order to minimize travels for teachers of French universities partners of the group, requiring, usually a very complicated logistics to find suitable time slots for both sides to schedule courses, it is desirable

\footnotetext{
${ }^{3}$ Blog : http://www.lemonde.fr/moocs-docs/article/2015/05/05formation-continue-les-mooc-font-leur-timiderevolution_4627894_4468700.html
} 
and beneficial for partners to apply our approach to training and assessment and allow learners to follow distance learning and online through MOOCs [18].

\section{REFERENCES}

[1] F. Vachon « Préparation des nouveaux enseignants et intervenants en FAD au canada francophone », document préparé pour le réseau d'enseignement à distance du canada (REFAD), www.REFAD.ca, 2013.

[2] http://blog.educpros.fr/yves-epelboin/2015/10/18du-nouveau-a-louest-des-mooc/

[3] http://www.enssup.gov.ma/index.php/48-top-menu/etudiants/222-programme-injaz.

[4] http://www.maroc.ma/fr/actualites/le-ministere-de-lenseignement-superieur-lance-leprogramme-lawhati.

[5] http://www.mooc.univh2c.ma/

[6] https://fr.wikipedia.org/wiki/France_Universit\%C3\%A9_Num\%C3\%A9rique.

[7] J. K. Waters «Breaking the MOOC model », Campus technology, janvier 2014, http://online.qmags.com/CPT0114?pg=7\&mode=1\# pg18\&mode1.

[8] J.A. Konstan, J.D. Walker, D.C. Brooks, K. Brown, M.D. Ekstrand «Teaching Recommender Systems at Large Scale: Evaluation and Lessons Learned from a Hybrid MOOC »ACMTrans. Comput.-Hum. Interact. 22, 2, Article 10 (April 2015), 23 pages. http://dx.doi.org/10.1145/2728171.

[9] JA Konstan, JD Walker, DC Brooks, K Brown and MD Ekstrand « Teaching recommender systems at large scale: Evaluation and lessons learned from a hybrid MOOC », March 4-5, 2014, Atlanta, Georgia, USA, - ACM Transactions on ..., 2015 - dl.acm.org

[10] Jean-Charles Pomerol Yves Epelboin Claire Thoury «Les MOOC Conception, usages, et modèles économiques » ISBN 978-2-10-071283-0, Paris 2014 DUNOD.

[11] Jean-Charles Pomerol Yves Epelboin Claire Thoury «Les MOOC Conception, usages, et modèles économiques» ISBN 978-2-10-071283-0 Paris 2014 DUNOD, paragraphe 4.2, pages [88-94].

[12] Jean-Charles Pomerol Yves Epelboin Claire Thoury «Les MOOC Conception, usages, et modèles économiques» ISBN 978-2-10-071283-0, Paris 2014 DUNOD, les pages 11, 12 et 13.

[13] Kabbaj, M. Talbi, M. Drissi My, M. Abouhanifa, S. (2009). Programme GENIE au Maroc : TICE et développement professionnel. Mathématice. $\mathrm{N}^{\circ} 16$. Septembre. En ligne http://revue.sesamath.net/spip.php?article233.

[14] KARSENTI, Thierry GARRY, Raymond-Philippe, BENZIANE, Abdel-Baki, NGOY-FIAMA Balthazar Bitambile et BAUDOT, Fabienne (2012). « La formation de formateurs et d'enseignants à l'ère du numérique : stratégies politiques et accompagnement pédagogique, du présentiel à l'enseignement à distance. Montréal » : Réseau international francophone des établissements de formation de formateurs (RIFEFF) / Agence universitaire de la Francophonie (AUF).

[15] Monter un MOOC de A à Z, vidéos de Matthieu Cisel Professeur de l'ENS de Cachan chapitre Scénarisation des activités d'évaluation, https://www.france-universite-numeriquemooc.fr/courses/ENSCachan/20002S04/session04/courseware/

[16] Moroccan Academic and Research Wide Area Network (MARWAN): http://www.marwan.ma/

[17] PA. Caron, J. Heutte and M. Rosselle « Présentation d'une méthode et d'outils pourévaluer les perceptions des apprenants dans un MOOC », Conférence JOCAIR 2014.

[18] Pascal Engel « Qualité de la Science Française », http://www.qsf.fr/2013/05.24/les-moocscours-massifs-ou-armes-de-destruction-massive.

[19] R. Bachelet Cours de Gestion de projet, ABC management de projet http://gestiondeprojet.pm/ 
[20] R. Bachelet, (2013-2014-2015) compilation des interventions disponibles en vidéo, des diapositives de présentations http://gestiondeprojet.pm/mes-contributions-surles- MOOC.

[21] S. Zheng, MB. Rosson, PC. Shih and M. Carroll "Understanding Student Motivation, Behaviors, and Perceptions in MOOCs", CSCW 2015, March 14-18, 2015, Vancouver, BC, Canada.

[22] Stéphanie Delpeyroux, Rémi Bachelet. Intégrer un MOOC dans un cursus de formation initiale. Colloque Questions de Pédagogie dans I'Enseignement Supérieur (QPES) 2015, Jun 2015, Brest, France. 2015, Actes du Colloque Questions de Pédagogie dans l'Enseignement Supérieur (QPES) 2015. http://www.colloque-pedagogie.org/.

[23] Thierry Karsenti « MOOC Révolution ou simple effet de mode ? Revue internationale des technologies en pédagogie universitaire 2013, http://www.riptu.org. 